Estudios sobre el Mensaje Periodístico

ISSN-e: 1988-2696

http://dx.doi.org/10.5209/ESMP.55604

\title{
[en] The Study of Laban Movement Analysis (LMA) in Shadow Puppets Theatre
}

\author{
Dahlan Abdul Ghani ${ }^{1}$
}

Received: January 28, 2016 / Accepted: September 2, 2016

\begin{abstract}
The art of shadow play within the Malaysian Wayang Kulit is unique with rich articulated translucent shadow movement but unfortunately it is slowly dying. In the past, the movement of puppets and shadows are performed by the skilled and experienced puppeteers or 'Tok Dalang'. Without realizing it that puppets movement are driven or influenced by human bodily motion. With the current scenario of shadow play is slowly being imminent extinct, we would like to discuss relationship between Laban Movement Analysis (LMA) in Wayang Kulit puppets movement. This research will focused on main areas that were identified in Wayang Kulit within LMA theory such as physical, space, shape, and effort. This research will hope that it will provide a tacit knowledge that LMA theory exist and applicable in shadow puppets or Wayang Kulit that would benefit for future research.
\end{abstract}

Keywords: Wayang Kulit; puppets; shadows; puppeteers; human motion; Laban Movement Analysis (LMA).

\section{Estudio del Análisis del Movimiento Laban (LMA) en el Teatro de Títeres de Sombras}

Resumen. El arte del juego de sombras dentro de la Wayang Kulit de Malasia es único con el movimiento de la sombra translúcida articulada, pero, por desgracia, se está muriendo lentamente. En el pasado, el movimiento de títeres y sombras se realizaban por los titiriteros experimentados o "Tok Dalang”. Esta investigación se centrará en las principales áreas que se identificaron en Wayang Kulit dentro de la teoría de LMA, tales como lo físico, el espacio, la forma y el esfuerzo. Esta investigación espera que proporcione un conocimiento tácito sobre la existencia de la teoría comunicativa LMA y que pueda beneficiar a futuras investigaciones.

Palabras clave: Wayang Kulit; títeres; sombras; titiriteros; movimientos humanos; Análisis del Movimiento Laban (LMA).

Summary. 1. Introduction. 2. Shadow Puppets Choreograph (Body Language \& Design). 3. References.

How to cite this paper: Ghani, Dahlan Abdul (2017): "The Study of Laban Movement Analysis (LMA) in Shadow Puppets Theatre", in Estudios sobre el Mensaje Periodístico 23 (1), 409-416.

\section{Introduction}

The word" Wayang "can be described as performance, puppet or character (Mrazek, 2005: 5). In Malaysia, Wayang Kulit Siam or known as Wayang Kulit Kelantan is a prod-

1 Universiti Kuala Lumpur. Malaysian Institute Information Technology.

E-mail: dahlan@miit.unikl.edu.my 
uct of Malay villages and most popular type of Wayang Kulit in state of Kelantan. The shadow play in Kelantan is performed primarily as a form entertainment in the towns and villages, for many people, and in the evening's a diversion from the routine daily life (Matusky, 1997: 14). The shadow play or Wayang Kulit is a unique form of theatre, with pulsating shadows motions and music creating fidelity to audience. The audience is delighted and impressed when out of such a simple setting, like the Wayang stage, emerge living visuals representing various forms such as gods, human, and animals that for the moments pulse with life (Osnes, 1989: 158). The shadow theatre is much of a stage to express ideas and experiences within human notions. Kierkegaard himself ascribes to the theatre a status of "artificial actuality" or "shadow existence. The theatre is a medium of the imagination and, as such, it separates man from existence. In Wayang Kulit, there basically four main elements are required in order to performed, includes puppets, Dalang, the paraffin light source and screen or known as "Kelir". The puppets are vital in order to established notion attention and phenomenon between the audience and the performer (puppeteer). A puppet is, of course, an object, and, of course, one that is animated, or manipulated, performed with (Bass, 1999: 35). Shadow puppets or Wayang Kulit accommodate an open array of possibilities portraying as object or metaphors for interpretation and action while capture the essential features of affect, meaning and intention that suggesting human narrative propensities, motion and emotional responses. As the puppets projecting emblem shadows, can be describe as the 'true puppet', being the moving shadow itself bound to the screen as flat, whose life is independent of the opaque or translucent silhouette cow hide leather, that cast it (Gross, 2011). The visual aesthetics of Wayang Kulit or shadow puppets rely on gestural motion and proportion. Puppeteers or known as Tok Dalangs in Wayang Kulit are manipulators, able to manipulate the puppets with artful notion of sense and touch, by moving in and out of view, lifting a figure a little from the screen and pressing it closely, with the edge turning sharp and soft within each frame of motion. With various plurality forms of shapes and sizes, the puppets and shadows appearance are nuance that fulfil the audience attention and aspiration.

The Laban Movement Analysis (LMA) is an study of science involving gestural and movement of human body which human are exposed to 'experience' realm of the world. It was designed by Rudolf Laban who was a architect and painter and became fascinated with rituals, folklore, mythology, dancing, art and mathematics. He saw human life as a dynamic movement experience and looked upon movement as a two (2) way language process through which the body could communicate by giving and receiving messages. He believed that movement stems from the inter-dependence of body, mind and spirit and he understood that our inner life relates to the outer world. Merleau-Ponty (1962) described that within the world of phenomenology and perception, the art of movement is considered vital. Laban theory of movement, is basically explaining the art of visual and choreographed context of varieties exist in human motion. LMA provides a conceptual framework through which we can observe, describe and interpret the intentionality of movement. It possesses one key attribute that the Animation Principles are without - the link between how people move and what their movement communicates to others. LMA can be divided into Five (5) categories that delineate the full spectrum of LMA's movement parameters: Body, Effort, Shape, Space and Phrasing. Phrasing describes how we sequence and layer the components of movement over time. Motion is the process of something moving or changing place or even just changing position. It involves three (3) main fundamentals which includes speed, velocity and acceleration. Movement or motion 
phrase is analogous to a verbal sentence, or to a phrase of music, in which a complete idea or theme is represented. A phrase unit involves three main stages: Preparation, Action and Recuperation. Our uniqueness is expressed through our movement phrases: individualized rhythmic patterns and preferences of Body, Effort, Shape and Space. How one initiates a phrase of movement organizes intent and patterns the neuromuscular coordination of the action (Hackney, 1998).

In context of human interaction, the art of interplay between human anatomy, body and mind (conscious or sub-conscious), action, reaction and perception provides a variety of forms of visual body that interacts with technology expectation. Keleman (1985) in his Emotional Anatomy, described that the body structure of humans are forms of expressions between fiction, history and reality. He added that anatomy functions as morphology kinetic cycle that morphs shapes of human with feelings and expression of patterns (Keleman, 1985: 59). He then conclude that the patterns exist in human anatomy are much of cells that organize the cognitive and perception automate in human body motions.

The art of human body movement has to be experienced and comprehended as an entirety. This is a means of training not only observation but also movement imagination, and the immediate connection with the practical application of bodily exertion in terms of artistic expression (Laban, 1971: 27). The human motions or movement with proper perception are also exist in shadow puppets or Wayang Kulit visual styles. The art of movement which are controlled and manipulated by the puppeteer are very much coherent with Laban's theory of movement. The physics of puppet anatomy and shadows projected are much unique and has much similar expressions and notions with human body structure Therefore, this research will look into several pillars of Laban theory that can be found in shadow puppets artistic.

\section{Shadow Puppets Choreograph (Body Language \& Design)}

According Hangendoorn (2009) choreography visualize the set of instructions for the organization and reconfiguration of one or several bodies in space and time. It provides a quantum of space within artistic, chemistry and momentum of each movement. The human body is designed from many things such as a mechanical device, a walking chemistry set, a sustainable life form, and an ever-changing biological phenomenon. The Body category describes structural aspects of the body in motion: which parts are moving or held, how movement flows from one part to the next (which is the essence of Follow Through and Overlapping), how the kinetic chains of the body are being patterned and coordinated, and postural habits from which gestural expression emerges. While this category has a focus on functional, or biomechanical aspects of movement, its parameters help us observe the degree of ease within the body and the ways in which the body serves authentic expression as the vehicle of its outward manifestation. The puppets and humans are basically able to move dynamically well because these bodies are a principal tool in the storytelling process. In addition to being able to use our bodies to communicate on the stage we invariably need to overcome our own physical idiosyncrasies, habits and movements so that our characters can be created from a blank physical slate rather than bringing our own personal bodies. The master puppeteer controls the movement of puppets from each side that provides depth and notion. This motion or so called "movement" is what separates the stuffed animal 
from the moving form we call a 'puppet'. Through movement in puppets, objects of the world, animate as well as inanimate, come to life.

The element of movement in a shadow puppet merges naturally with human expressiveness in language and renders all matter potentially lifelike, manipulable, poetic, versatile, kinetic and eye-catching (Peyton, 2011). The meaning of Laban Movement Analysis(LMA) which involved theoretical and experiential system for the observation, description, prescription, performance, and interpretation of human movement, could be easily translate into each segmentation movement or choreograph orchestra by the master puppeteer. As Rudolph Laban perceive that human existence is two (2) way language process through which the body could communicate by giving and receiving messages which he believed that movement stems from the inter-dependence of body, mind and spirit and he understood that our inner life relates to the outer world. Else, in shadow puppet itself has own significance that provides between the real and unreal world. Laban's theories can be easily define or viewed in three parts: what moves; how do we move and where do we move? Is this theories relevant within the dogma of shadow puppetry or Wayang Kulit? The visual qualities of translucent shadows that exist in and out from the "Kelir" or screen has provided vicious or vivid notion of souls that the audience perceive. If human uses the 'send' and 'receive' signals to communicate, shadow puppets also has the similar juxtaposition of qualities of communication which is the shadow and the puppeteer.

Basic shadow puppets has a complete complement of puppet are divided into ten(10) groups such as dewa-dewa (demigods), satria (warriors), raksasa (jins\&gnomes), orang betapa (hermit), monyet (monkey), Kayon and haiwan(animals) and each character has its own identity. Here, the design of the puppet anatomy characters including archetypes are vital in presenting the persona or identity for each character with physical design qualities of aethethhics, soul, and miracles of existence. According to Rudolf Laban, the astonishing structure of the body and the amazing actions it can perform are some of the greatest miracles of existence. Each phase of a movement, every small transference of weight, every single gesture of any part of the body reveals some feature of our inner life." 'The body doesn't lie. Everything begins with a form (anatomy) and from the body. The mind and the body do not function separately - they are intimately linked as an organic whole.

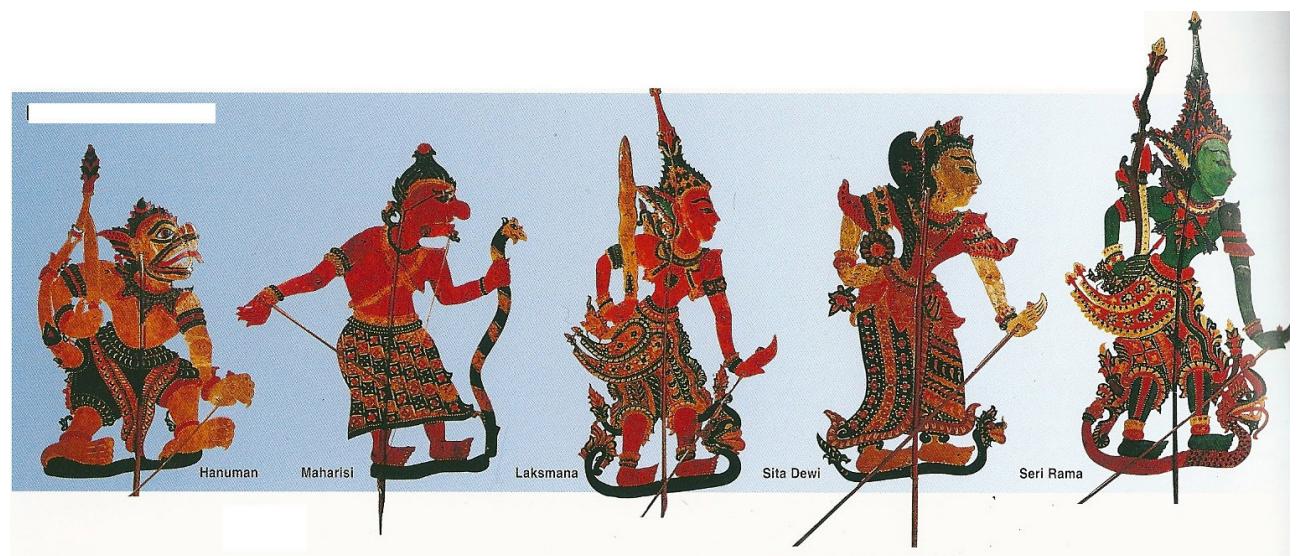

Figure 1. Wayang Kulit Kelantan Shadow Puppet Anatomy Structure 
A basic Wayang Kulit Kelantan set consists of $65-120$ puppets and each puppets representing the principal characters. The puppets shown in Figure 1.0 are Kelantanese shadow puppets design by Pak Hamzah himself applies detail crafting, articulation, joints and variety character traits that enables to project translucent silhouette colour effects projected on the Kelir or white screen. Most of the characters are in the mode of 'choreograph' shown in Figure 1.0 which represents between art, space, culture and rhythm. It similar to Laban resemblance of Human body that it was thus freed to find its own rhythms, dream up its own steps, and delight in the medium of its own space. The influence of each puppet character has strong gestural symbolism or dogma that provides a different inner life. It creates a kind of free or relaxation mind that enables the body to flow or move adequately. In other words, Laban's theory or ideas were heavily influenced by the social and cultural changes of the time and the contexts that he worked in (Karina and Kant, 2003). There were certain traditional constraints in the dance world against showing feeling in movement. He challenged this way of thinking and paved the way for a freeing of the "feeling body." Laban believed the best way to advocate this freedom was by applying it to his own artistic movement with small amount of influence. The character 'Seri Rama' for instance viewing from the body structure it is clear where Thai and Javanese shadow puppet influences have affected it. In this respect a closer examination of the Seri Rama characters reveals the noteworthy fact that, while these puppets do have certain structructural features in common in the body and they do deviate from the shoulders downwards, he structure of the face is basically constant, though the expression as a delineation of Rama's character varies greatly.

The master puppeteer or known as Tok Dalang choreographed each movement that creates unity and continuity between each transition of shadows within spatial area. It comes with variety, with less cliché or stereotype motion that enable the audience to mesmerize each notion of shadow with uncanny emotions. According to Minton (2010), although there is no single approach to creating a dance that has a clear sense of development, certain characteristics are common to many effective pieces of choreography. Those qualities are unity, continuity, transition, variety, and repetition. Unity in each dance movement are essential. The separate movements in the choreography must flow together, and each must contribute to the whole; eliminate phrases not essential to the intent of the work. An example of a dance that lacks unity is one in which all movements seem at first to have the same character or ambience about them, but then suddenly a movement or series of movements appears that is very different in feeling. Such movements do not fit with the feeling of the choreography; rather, they stand out as distinct from the essence of the piece and interfere with the interconnectedness of the dance. Laban suggested that the art of choreographed dance should be accessible to everyone because it was a way for people to reconnect with their communities and nature in an increasingly mechanized world. There is a great deal of shadow puppet movement that consist of cyclical in nature rather than linear. In other words, this type of movement might seem monotonous if not for creative music ensemble The world of shadows offers a significance between human, god and rhythm (choreograph of narrative, shadows, puppets) that provides conceptual and higher understanding (Osnes, 2010).

Space provides the essence of continuity within each dance or shadow play motion. For Laban (1966), space is therefore the volume occupied by an outreaching body-what he calls a "personal space" (p. 10). Laban spoke of space specifically in 
terms of an area within reach of the body's extended limbs, which when projected in all directions from the bodily centre can be conceived as a totality of movement or a sphere of movement. According to Salazar Sutil (2014), Laban has discovered two (2) Seeing as the approach in question is essentially a multimodal visual method, Laban sees harmonic movement as a production of visual forms. The outer forms or kinespheric actions constitute what Laban calls trace forms, that is, points linked up into a line or pathway that is the trajectory made by a moving body as it traverses kinespheric space. Laban then speaks of shadow forms, which are derived from what he calls action-moods, which in turn are actions that are expressions of inner drives (emotions and psychological forces).

Unlike trace forms, shadow forms create relations that are not extensive, but intensive. Thus, to understand a dynamospheric movement, one has to consider positions that are constantly changing within the inner dynamics of human beings. These inner stresses are expressed as shadow forms, which according to Laban peak and decline. What is key to understanding these inner forms is not how many of them are produced, or how many body parts are used, or how long it takes to execute them. What is important is the quality of movement it produces, that is, whether the movement is strong, whether it is light, whether it is bound or free-flowing. But the shadows trajectory movement are elusive, vivid and strong that able to engaged the audience with puppets through the artistic manipulating skilled performed by the puppeteer.

According to Jan Mrazek (2005), the choreographed movement is presented as physical blow in Javanese or Kelantanese Wayang Kulit described by Stephen Salel related to what happens to the puppet when it is moved in performance. The puppet 'stands' it is placed more or less vertically on the screen (Fig. 2 A) shows process for the blow, the whole puppet is moved backward quite like one would move a hammer or axe before it strikes (Fig 2 B). At the farthest point of the movement, the puppet is about horizontal, or even the puppet's head can be below the level of its feet (Fig 2 C). Then, to represent the blow, the puppet is thrust from that position at the other puppet similar if the puppeteer were thing a hammer (Fig.2 D), the particular part of the puppet that is hitting (such as the puppet hand) is aimed at the particular part of the puppet that is to be hit (such as chest or head).

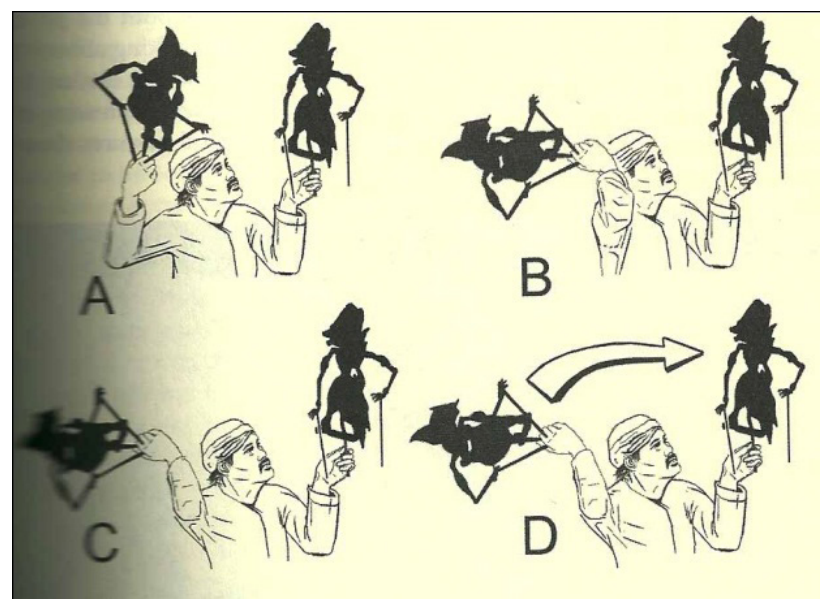

Figure 2. The puppeteer animating the puppets 
Finally, the hitting movement representing the blow is both forceful and controlled. The movement in this artistic Wayang Kulit are similarity of the puppet to be represented being so slight or remote that is unidentifiable. Certain puppets are portrayed with meaning through action, movement, special effect of fire or lamps, speeches and delivered in a normal human voice while the puppet is motionless. Wayang Kulit can be different from the actors' theatre in that the character is not represented merely by the performer's body, but depiction by the puppet. As discussed earlier, it is clearly define that Wayang Kulit movement of puppets has the similar choreographed qualities to a dance performance. Even though in Wayang Kulit, the puppet statue is 'dead' or unreal world physically but comes to live (when controlled by human / puppeteer) where else 'dance' are controlled and guided by human the 'real-world'.

\section{References}

Bass, Eric (1999): "Notes on Puppetry as a Theatrical Art: Response to an Interview". Contemporary Theatre Review, 10 (1), 35-39. London, Rouledge.

Gross, Kenneth (2011): An Essay on Uncanny Life. Volume 1. Chicago, University Chicago Press, pp. 125-126.

Hackney, Peggy (1998): Making Connections; total body integration through Bartenieff Fundamentals. Netherlands, Gordon and Breach, pp. 237-239.

Hangendoon, Ivar (2008): "Emergent patterns in dance improvisation and choreography". In Unifying Themes in Complex Systems, IV, 183-195. Springer Berlin Heidelberg.

Karina, Lilian \& Kant, Marion (2003): Hitler's Dancers: German Modern Mance and the Third Reich. New York, Berghahn Books.

Keleman, Stanley (1985): Emotional Anatomy. Berkeley, Center Press. ISBN 0-934320-10-1.

Kierkegaard, Sören (1967): Soren Kierkegaard's Journals and Papers [trans. Howard V. and Edna Hong]. Bloomington, Indiana University Press,\#1051 and \#4881

Laban, Rudolf (1966): Choreutics (Ulmann, L. Ed.). London, England: Macdonald \& Evans. Matusky, Patricia (1997): "Malaysian Shadow Play \& Music, Continuity of an Oral Tradition". The Asian Centre Press, Penang, pp.12-17

Merleau-Ponty, Maurice (1962): Phenomenology of Perception. Routledge Classic, London, 2nd Edition, pp. 45

Minton, Sandra Cerny (2010): "How to make choreography more effective" [Online Article] DOI. http://www.humankinetics.com/excerpts/excerpts/characteristics-of-Effective-choreography

Mrazek, Jan (2005): Phenomenology of a Puppet Theatre,: Contemplations on the art of Javanese Wayang Kulit. KITLV Press, Royal Netherlands Academy of Arts \& Science, pp. 5-12

Osnes, Beth (1989): The Study of Wayang Kulit Kelantan. Phd Thesis. Department of Dance, University of Colorado, pp. 157-158

Osnes, Beth (2010): "The Shadow Puppet Theatre of Malaysia: A Study of Wayang Kulit with Performance Scripts and Puppet Designs". McFarland Press, US, pp.120-130

Peyton, Jeffrye L. (2011): "An Analysis Of The Qualities In Puppets". [Online Article] DOI. https://www.puppetools.com/!getpublicfile.php?fid=155

Salazar Sutil, Nicolas (2014): "Performance/mathematics: a Dramatisation of Mathematical methods". International Journal of Performance Arts and Digital Media, 10 (2), 143-158. 
Dahlan Abd Ghani is Senior Lecturer at Univerity Kuala Lumpur and has vast eperience in Animation, Media \& Puppetry Studies for almost 14 years. Dr Dahlan has won several local \& international recognition related to publishing high impact research article on Animation,Media \& Puppetry studies. He earn his first degree from Multimedia University, Malaysia and continue his Masters in National University Malaysia and Graduated his PhD Studies in Animation \& Puppetry studies from University Malaya in 2015. 